\title{
Causes of Compositional Diversity in the Olivine Melilitites of Namaqualand- Bushmanland, South Africa
}

Janney, P.E.1,2, le Roex, A.P.2

1. Scripps Institution of Oceanography, University of California, San Diego, La Jolla, CA 92093-0220, USA (email: pjanney@ucsd.edu)

2. Department of Geological Sciences, University of Cape Town, Rondebosch 7700 , South Africa

One of three major provinces of mafic alkaline diatremes intruded on the southwestern African margin during Late Cretaceous-Early Tertiary time, the numerous olivine melilitite pipes of NamaqualandBushmanland form a linear swarm extending roughly $250 \mathrm{~km} \mathrm{NE}$ from the west coast of South Africa near Garies. The Namaqualand melilitites may represent the southwesternmost extremity of an even longer $(\approx 500 \mathrm{~km})$ magmatic lineament comprising kimberlites from the Pofadder, Border/Orange River and Rietfontein areas. Limited radiometric dating indicates that the intrusions show a rough age progression (56-77 Ma) with ages generally decreasing toward the coast (Moore and Verwoerd, 1985).

The olivine melilitites are dominated by olivine as the only major phenocryst phase and also an important groundmass component. The diatremes fall into two distinct groups on the basis of location and composition (Moore, 1979). The coastal Garies group is significantly evolved, with Mg-numbers of 51 to 62 , low $\mathrm{SiO}_{2}$ contents (30-34 wt.\%) and very high incompatible element abundances (e.g., $\mathrm{Zr}=800-1200 \mathrm{ppm}$ ). The inland Gamoep group, on the other hand, is more primitive $(\mathrm{Mg} \#=70-77)$, with higher $\mathrm{SiO}_{2}(34-38 \mathrm{wt} \%)$ and much lower abundances of incompatible elements (e.g., $\mathrm{Zr}=260-450 \mathrm{ppm}$ ). To a first approximation, the main compositional differences between the two groups can be explained by variations in the extent of olivine fractionation, with the Garies group magmas having crystallized 30 to $60 \%$ olivine during ascent, assuming initial equilibrium with mantle olivine ( $\left.\mathrm{Fo}_{90}\right)$. The high degree of fractionation displayed by the Garies melilitites is much greater than that seen in any other mafic alkaline diatremes from southern Africa and may indicate that their parental melts accumulated and fractionated in shallow magma chambers before ascending to the surface.

All of the melilitites are strongly depleted in $\mathrm{K}$ relative to other elements of similar incompatibility (e.g., $\mathrm{Nb}, \mathrm{La}$ ), which suggests that they formed in the presence of a residual K-bearing phase. Subequal negative $\mathrm{Rb}$ and $\mathrm{Ba}$ anomalies on primitive mantle-normalized trace element diagrams and the presence of phlogopite as a groundmass phase even in primitive samples suggests that this residual phase is phlogopite (e.g., Rogers et al., 1992).

The Namaqualand melilitites display fairly coherent variations in $\mathrm{Sr}, \mathrm{Nd}$ and $\mathrm{Pb}$ isotopic and trace element ratios that appear to record a systematic shift in source composition similar to, but less extreme than, that observed in melilitites from the Western Cape (Janney et al., this volume). Both the Garies and Gamoep groups contain diatremes displaying HIMU isotopic affinities $(87 \mathrm{Sr} / 86 \mathrm{Sr}=$ $\left.0.7031-0.7033, \varepsilon_{\mathrm{Nd}}(\mathrm{t})=2.7-3.9,206 \mathrm{~Pb} / 204 \mathrm{~Pb}_{\mathrm{i}}>19\right)$, but some diatremes in the Gamoep group have higher $87 \mathrm{Sr} / 86 \mathrm{Sr}_{\mathrm{i}}$ (up to 0.7038 ) and lower $206 \mathrm{~Pb} / 204 \mathrm{~Pb}$ values (down to 18.0 ), likely indicating a greater contribution from old metasomatized continental lithosphere with an EM 1 isotopic affinity (e.g., Hawkesworth et al., 1990). This is also suggested by gradual increases in $\mathrm{Th} / \mathrm{Nb}(0.03$ to $0.09)$ and $\mathrm{Nb} / \mathrm{Zr}(0.2$ to 0.5$)$ ratios in diatremes from the coast to the interior. These ratios are sensitive to carbonatite metasomatism and likely indicate greater involvement of metasomatized lithospheric peridotite in the melilitites intruded through the thickest lithosphere. Further evidence of lithospheric interaction is shown by the Hoedkop diatreme, located furthest inland and with the greatest lithospheric geochemical affinity, which contains abundant spinel and garnet peridotite xenoliths. 
The HIMU signature of the Namaqualand melilitites has been attributed to metasomatism of the regional lithospheric mantle by a low-degree silicate melt generated in the presence of residual phlogopite (Rogers et al., 1992). However, the HIMU component has been recognized as a mixing endmember common to melilitites, carbonatites, Group 1 kimberlites and other mafic alkaline magmas from across southern Africa (e.g., Smith, 1983; Halliday et al., 1988; Bell and Blenkinsop, 1989), arguing against a regional metasomatic origin. Rather, the widespread occurrence of the HIMU signature, and the fact that it is most strongly expressed in regions having the thinnest lithosphere, suggests that the HIMU composition originates from a domain located at the base of the lithosphere, possibly ancient subducted, underplated oceanic crust.

The formation of the age-progressive Namaqualand magmatic lineation can be most simply explained by the action of a stationary mantle hotspot providing a heat source to melt the sub-lithospheric HIMU domain, which must reside near the interface between the mechanical and thermal boundary layers in order to remain in convective isolation (e.g., Wilson et al., 1995). During ascent, these melts interacted with and variably assimilated metasomatized lithospheric material, causing the observed ranges in isotopic and trace element composition.

\section{References}

Bell, K. and J. Blenkinsop, 1989, Neodymium and strontium isotope geochemistry of carbonatites: In Carbonatites: Genesis and Evolution, edited by K. Bell, Unwin and Hyman, London, p. 38-69.

Halliday, A.N., A.P. Dickin, A.E. Fallick and J.G. Fitton, 1988, Mantle dynamics: a Nd, Sr, Pb and $O$ isotopic study of the Cameroon Line volcanic chain: J. Petrol., 29, p. 181-211.

Hawkesworth, C.J., A.J. Erlank, P.D. Kempton and F.G. Waters, 1990, Mantle metasomatism: isotope and trace element trends in xenoliths from Kimberley, South Africa: Chem. Geol., 85, p. 19-34.

Moore, A.E., 1979, Geochemistry of the olivine melilitites and related rocks of NamaqualandBushmanland, South Africa, $\mathrm{PhD}$ dissertation, University of Cape Town.

Moore, A.E. and W.J. Vorwoerd, 1985, The olivine melilitite-"kimberlite"-carbonatite suite of Namaqualand and Bushmanland, South Africa: Trans. Geol. Soc. S. Afr., 88, p. 281-294.

Rogers, N.W., C.J. Hawkesworth and Z.A. Palacz, 1992, Phlogopite in the generation of olivinemelilitites from Namaqualand, South Africa and implications for element fractionation processes in the upper mantle: Lithos, 28, p. 347-365.

Smith, C.B., 1983, Pb, Sr and Nd isotopic evidence for sources of southern African Cretaceous kimberlites: Nature, 304, p. 51-54.

Wilson, M., J.M. Rosenbaum, E.A. Dunsworth, 1995, Melilitites: partial melts of the thermal boundary layer?: Contrib. Mineral. Petrol., 119, p. 181-196. 


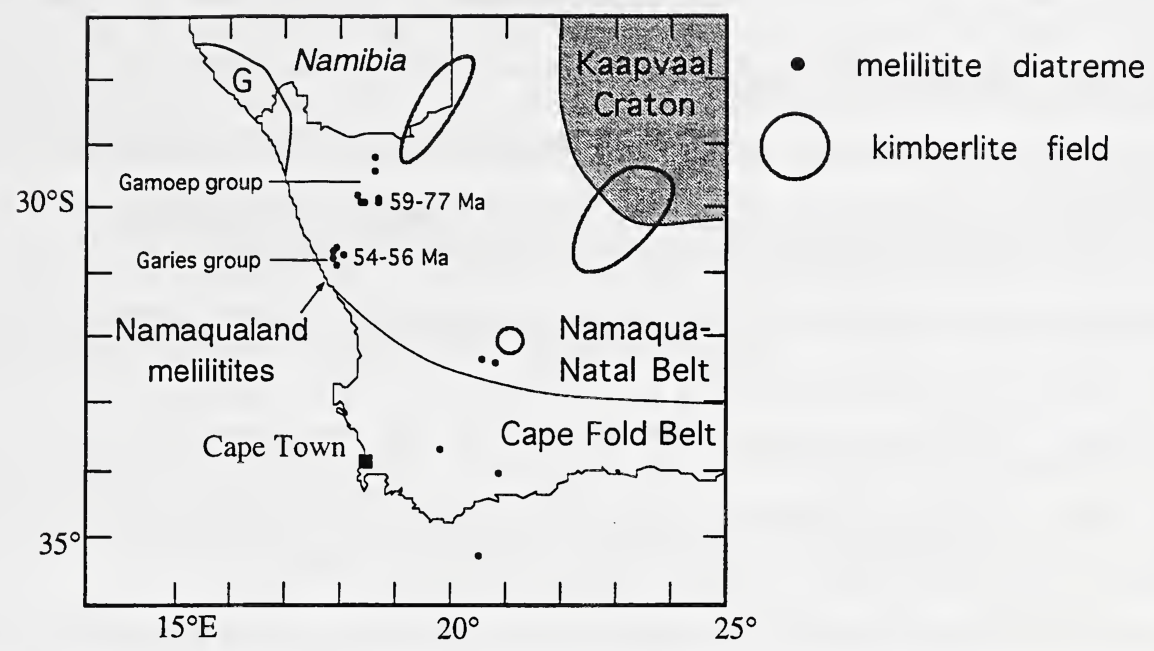

Figure 1. Location map showing the tectonic setting of the Namaqualand melilitites and other mafic alkaline diatremes in western South Africa

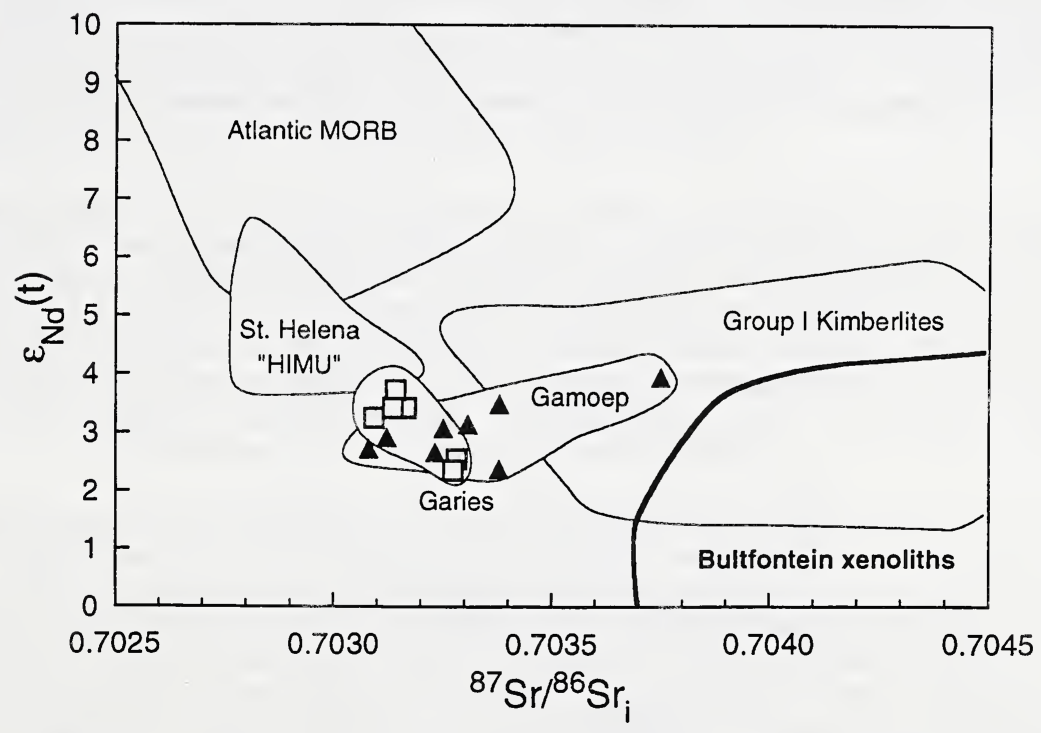

Figure 2. Sr vs. Nd isotopic data for Garies and Gamoep group melilitities from Namaqualand. Note that the Garies group displays isotopic characteristics similar to HIMU ocean islands whereas the Gamoep group extends toward higher $\mathrm{Sr}$ isotopic ratios, similar to Group 1 kimberlites. 